Published as: Nat Immunol. 2008 June ; 9(6): 641-649.

\title{
The differentiation of human $\mathrm{T}_{\mathrm{H}}-17$ cells requires transforming growth factor- $\beta$ and induction of the nuclear receptor RORYT
}

\author{
Nicolas Manel ${ }^{1}$, Derya Unutmaz ${ }^{2}$, and Dan R. Littman ${ }^{1,3,4}$ \\ 1 The Kimmel Center for Biology and Medicine of the Skirball Institute, New York University School of \\ Medicine, New York, New York 10016, USA \\ 2Department of Microbiology, New York School of Medicine, New York, NY 10016, USA \\ 3Howard Hughes Medical Institute, New York University School of Medicine, New York, New York 10016, \\ USA \\ 4Departments of Pathology and Microbiology, New York University School of Medicine, New York, New York \\ 10016, USA
}

\section{Abstract}

T helper 17 cells $\left(\mathrm{T}_{\mathrm{H}^{-}} 17\right.$ cells) are interleukin 17 (IL-17)-secreting $\mathrm{CD}^{+} \mathrm{T}$ cells involved in autoimmune disease and mucosal immunity. In naive $\mathrm{CD} 4^{+} \mathrm{T}$ cells from mice, IL-17 is expressed in response to a combination of IL- 6 or IL-21 and transforming growth factor- $\beta$ (TGF- $\beta$ ) and requires induction of the transcription factor ROR $\gamma \mathrm{t}$. It has been suggested that human $\mathrm{T}_{\mathrm{H}^{-1}}$ - cell

differentiation is independent of TGF- $\beta$ and thus differs fundamentally from mouse. We show here that a combination of TGF- $\beta$, IL- $1 \beta$ and IL-6, IL-21 or IL- 23 in serum-free conditions was necessary and sufficient to induce IL-17 expression in naive human $\mathrm{CD}^{+} \mathrm{T}$ cells from cord blood. TGF- $\beta$ upregulated ROR $\gamma \mathrm{T}$ expression but at the same time inhibited its ability to induce IL-17 expression. Inflammatory cytokines relieved this inhibition and increased IL-17 expression directed by ROR $\gamma \mathrm{T}$, similar to what has been reported with mouse cells. Other gene products detected in $\mathrm{T}_{\mathrm{H}^{-}} 17$ cells upon ROR $\gamma$ T induction include CCR6, the IL-23 receptor $(I L 23 R), I L 17 F$ and $I L 26$. Together, these studies identify ROR $\gamma \mathrm{T}$ as having a central role in differentiation of human $\mathrm{T}_{\mathrm{H}^{-}} 17$ cells from naive $\mathrm{CD}^{+} \mathrm{T}$ cells and suggest that similar cytokine pathways are involved in this process in mouse and human.

$\mathrm{T}_{\mathrm{H}^{-}}-17$ cells, the $\mathrm{T}$ helper cells that produce IL-17 and other pro-inflammatory cytokines, have been shown to have key functions in a wide variety of autoimmune disease models in mice and are thought to be similarly involved in human disease (reviewed 1-3). In healthy humans, IL-17-secreting cells are present in the $\mathrm{CD}_{4} \mathrm{RO}^{+} \mathrm{CCR} 6^{+}$populations of $\mathrm{T}$ cells from peripheral blood4,5 and gut5. $\mathrm{T}_{\mathrm{H}^{-1}} 17$ cells or their products have been associated with the pathology of multiple inflammatory or autoimmune disorders in humans. IL-17 protein and $\mathrm{T}_{\mathrm{H}^{-}} 17 \mathrm{CD}{ }^{+} \mathrm{T}$ cells are found in lesions from multiple sclerosis patients6-8 where they are thought to contribute to the disruption of the blood-brain barrier9. IL-17 is produced by $\mathrm{CD} 4^{+} \mathrm{T}$ cells of rheumatoid synovium 10 and is thought to contribute to inflammation in rheumatoid arthritis11,12. In psoriasis, products associated with $\mathrm{T}_{\mathrm{H}^{-}} 17$ cells, including IL-17, IL-17F, IL-22, and CCR6 are induced13-15. IL-17 is induced in the gut mucosa from Crohn's disease and ulcerative colitis patients and $\mathrm{T}_{\mathrm{H}^{-}}-17$ cells are detected $13,16 . \mathrm{IL}-23$, which is produced by dendritic cells in the intestine 17 , contributes significantly to $\mathrm{T}_{\mathrm{H}^{-}} 17$ cell differentiation 18 . Strikingly, polymorphisms in the $I L 23 R$ gene are associated with Crohn's disease, further implicating the $\mathrm{T}_{\mathrm{H}^{-1}}$ cell pathway in the pathogenesis 19 . 
The mechanisms leading to differentiation of $\mathrm{T}_{\mathrm{H}^{-}} 17$ cells have been well established in mice but they are still poorly understood in humans. In mice, differentiation of $\mathrm{T}_{\mathrm{H}^{-}} 17$ cells that secrete IL-17 (also referred to as IL-17A) and IL-17F requires the expression of the transcription factors ROR $\gamma \mathrm{t}$, an orphan nuclear hormone receptor, STAT3 and IRF4 (reviewed in reference 20). ROR $\gamma$ t is sufficient to direct expression of IL-17 in activated mouse T cells 21 and is thus considered to be the effector transcription factor that establishes the $\mathrm{T}_{\mathrm{H}^{-}}-17$ differentiation lineage. Conditions that induce $\mathrm{T}_{\mathrm{H}^{-}} 17$ cell differentiation from naive murine $\mathrm{T}$ cells, including expression of ROR $\gamma \mathrm{t}$, have been established. Combinations of TGF- $\beta$ and IL-6 22-24 or TGF- $\beta$ and IL-21 25-27 are sufficient to initiate IL-17 and IL-17F expression.

Expression of IL-22, considered to be another $\mathrm{T}_{\mathrm{H}^{-}} 17$ cytokine, is induced by IL- 6 and inhibited by high concentrations of TGF- $\beta$ 14. IL-23 is required in vivo for the generation of pathogenic $\mathrm{T}_{\mathrm{H}^{-}}-17$ cells but it is not required in vitro for the induction of IL-17, IL-17F or IL-22 18 .

In contrast to murine $\mathrm{T}$ cells, human $\mathrm{T}$ cells with a naive surface phenotype failed to produce IL-17 in the presence of TGF- $\beta$ and IL-6 28-31. However, increased expression of IL-17 was observed by some groups in response to IL- $1 \beta$ alone 29 or with IL-23 15 . Others have failed to observe such a response 30 . This difference between the requirements for mouse and human $\mathrm{T}_{\mathrm{H}^{-}}-17$ cell differentiation was ascribed to divergent differentiation processes, although it remained possible that $T$ cells purified from adult peripheral blood on the basis of CD45RA expression alone would not be equivalent to naive murine T cells 32-34.

To avoid having antigen-experienced cells and serum-derived TGF- $\beta$ in the $\mathrm{T}_{\mathrm{H}^{-}}-17$ differentiation cultures, we have used human cord blood $\mathrm{CD} 4^{+} \mathrm{T}$ cells and serum-free medium. Under these conditions, induction of IL-17 and other $\mathrm{T}_{\mathrm{H}^{-}}-17$ gene products was observed only if TGF- $\beta$ was added to the culture medium. In contrast to requirements in mouse $T$ cell cultures, human $\mathrm{T}_{\mathrm{H}^{-}}-17$ cell differentiation was not observed when IL-6 or IL-21 was combined with TGF- $\beta$. Instead, a combination of IL- $1 \beta$ and IL-6, IL-21 or IL- 23 was required with TGF- $\beta$ for induction of IL-17 expression. As in mouse $\mathrm{T}_{\mathrm{H}^{-}} 17$ cell differentiation, ROR $\gamma \mathrm{T}$ was induced in human cells by TGF- $\beta$ and was required and sufficient for expression of $\mathrm{T}_{\mathrm{H}^{-}}-17$ cell products, suggesting that the basic mechanism of $\mathrm{T}_{\mathrm{H}^{-1}} 17$ cell differentiation is evolutionarily conserved.

\section{Results}

\section{RORYT-dependent IL-17 expression in human memory CD4 ${ }^{+} \mathrm{T}$ cells}

To evaluate the effect of IL-1 $\beta$ on IL-17 production, we sorted naive

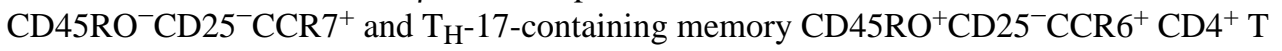
cells from adult peripheral blood and cultured them in serum-containing media in the presence or absence of IL-1 $\beta$. IL-1 $\beta$ induced a two-fold increase of IL-17 production in CCR6 $6^{+}$memory cells but had no effect on $\mathrm{CD}_{45 \mathrm{RO}^{-}}$cells (Fig. 1a). Similar results were observed with CD45RA ${ }^{+}$sorted cells (data not shown). With the goal of identifying requirements for $\mathrm{T}_{\mathrm{H}^{-}} 17$ cell differentiation in humans, we initially wished to evaluate whether ROR $\gamma \mathrm{T}$ was necessary in pre-committed $\mathrm{T}_{\mathrm{H}^{-}}-17$ cells to maintain effector function. To ablate ROR $\gamma \mathrm{T}$ expression we utilized two short hairpin RNAs (shRNAs) that demonstrated potent ability to 'knock-down' ROR $\gamma \mathrm{T}$ after transient transfection (data not shown). We transduced sorted $\mathrm{CD} 45 \mathrm{RO}^{+} \mathrm{CCR} 6^{+}$memory $\mathrm{CD}^{+} \mathrm{T}$ cells isolated from adult blood with the shRNA vectors. After 6 days, shRNA- 1 and shRNA-2 reduced ROR $\gamma$ T expression by $50 \%$ and $90 \%$, respectively (Fig. 1b). Correspondingly, we observed on average 2-fold and 3.2-fold decreases in IL- $17^{+}$cells with shRNA-1 and shRNA-2, respectively (Fig. 1c). The proportion of IFN$\gamma^{+}$cells remained high in all samples. Thus, ROR $\gamma \mathrm{T}$ is required for maintenance of IL-17 expression in differentiated $\mathrm{T}$ cells. 


\section{RORYT-induced cytokines from cord blood cells}

We next asked whether overexpression of ROR $\gamma \mathrm{T}$, that would bypass any requirement of its induction by cytokines, would be sufficient to obtain IL-17 expression in naive $\mathrm{CD} 4^{+}$human $\mathrm{T}$ cells. We isolated $\mathrm{CD} 4^{+} \mathrm{T}$ cells from human cord blood to ensure a naive phenotype, activated them with anti-CD3 and anti-CD28, and transduced them with control or human ROR $\gamma \mathrm{T}-$ encoding lentivirus. IL-17 expression was readily detected, peaking at 6 days in cells transduced with the ROR $\gamma$ T vector (Fig. 1d and data not shown). The proportion of IFN- $\gamma$ expressing cells was substantially reduced by the expression of ROR $\gamma \mathrm{T}$ (Fig. 1d). ROR $\alpha$ d and ROR $\beta$, two other ROR-family members, also induced IL-17 expression when over-expressed in primary human T cells (Supplementary Fig. 1 online).

We did not detect IL-22 protein induction with ROR $\gamma \mathrm{T}$ overexpression (data not shown). This was unexpected because IL-22 mRNA is strongly up-regulated by ROR $\gamma \mathrm{t}$ in murine $\mathrm{CD} 4^{+} \mathrm{T}$ cells (L. Zhou et al., unpublished observations). This apparent discrepancy between mouse and human led us to investigate the IL22 gene of various species (Supplementary Fig. 2a online). In human, the IL22 gene is located in the same locus as $I F N G$ and $I L 26$. In mouse, there is no Il26 gene, and Il22 is located in the same locus as Ifng and Iltifb, an Il22 duplication. IL-26, similarly to IL-22, is an IL-10 related cytokine and is found in memory CD4 ${ }^{+} \mathrm{T}$ cells expressing IL-1715. Quantitative PCR analysis of ROR $\gamma \mathrm{T}$-expressing cells indicated that IL26 is induced along with $I L 17$ and $I L 17 F$ by ROR $\gamma \mathrm{T}$ (Fig. 1e). The $I L 26$ gene was also found in the genome of pre-placental vertebrates, including zebrafish 35 , but not in the genome of rat and mouse (Supplementary Fig. 2b), suggesting that it was lost in a common ancestor for both rodents.

Human $\mathrm{T}_{\mathrm{H}^{-}} 17$ cells are exclusively found in the $\mathrm{CD} 45 \mathrm{RO}^{+} \mathrm{CCR} 6{ }^{+}$compartment in adult blood. However, this compartment also contains IFN- $\gamma^{+} \mathrm{IL}-17^{-}$and IFN- $\gamma^{+} \mathrm{IL}-17^{+}$cells. In order to determine which transcription factor could induce CCR6 expression in $\mathrm{CD}^{+} \mathrm{T}$ cells, we transduced cord blood $\mathrm{CD} 4^{+} \mathrm{T}$ cells with vectors encoding ROR $\gamma \mathrm{T}$ or the transcription factors involved in specification of the $\mathrm{T}_{\mathrm{H}} 1$ and $\mathrm{T}_{\mathrm{H}} 2$ cell lineages, $\mathrm{T}$-bet and GATA3, respectively, as well as a control empty vector. CCR6 was induced in ROR $\gamma$ T-expressing cells, but not in cells transduced with GATA3 or T-bet, and it was not induced in trans in cultures of ROR $\gamma \mathrm{T}$ expressing cells (Fig. 1f). Expression of CCR2 and CCR4, also suggested to be $\mathrm{T}_{\mathrm{H}^{-}} 17$ cell markers 4,36, was not altered by overexpression of ROR $\gamma \mathrm{T}$ (data not shown).

\section{Antagonistic effects of TGF- $\beta$ on RORYT function}

We next sought to determine how cytokines known to affect $\mathrm{T}_{\mathrm{H}^{-}} 17$ cells in mouse or human would affect IL-17 expression following ROR $\gamma \mathrm{T}$ overexpression, which circumvents the potential effect of the cytokines on ROR $\gamma \mathrm{T}$ expression per se. Cord blood $\mathrm{CD} 4^{+} \mathrm{T}$ cells were transduced with ROR $\gamma \mathrm{T}$ alone or in the presence of IL-1 $\beta$, IL-6, or IL-21 in combination with various concentrations of TGF- $\beta$ (Fig. 2a). Addition of IL-1 $\beta$, IL- 6 and IL-21 increased by about two-fold the proportion of IL-17-producing cells obtained after forced expression of ROR $\gamma$ T. However, TGF- $\beta$ potently suppressed IL-17 production. Interestingly, addition of IL-1 $\beta$, IL- 6 or IL-21 partially relieved the suppression induced by TGF- $\beta$. We then asked whether these cytokines could influence expression of endogenous ROR $\gamma \mathrm{T}$. We sorted $\mathrm{CD}^{2} 5 \mathrm{RO}^{-}$naive as well as subsets of memory $\mathrm{CD}^{+}{ }^{+} \mathrm{T}$ cells based on CCR6 and CCR4 expression from adult peripheral blood for comparison of RORC (the gene encoding for ROR $\gamma \mathrm{T}$ ) mRNA levels. RORC expression was enriched in CCR6 ${ }^{+}$cells. Various cytokines were screened for their ability to induce the expression of in $\mathrm{CD}^{2} 5 \mathrm{RO}^{-}$adult naive $\mathrm{CD}^{+} \mathrm{T}$ cells. Surprisingly, addition of TGF- $\beta$ alone induced dose-dependent $R O R C$ expression, but none of the other cytokines had such an effect (Fig. $2 b, c)$. However, treatment with TGF- $\beta$, alone or with IL-1 $\beta$, IL-6 or IL-21, was insufficient to induce significant IL-17 expression as detected by intracellular staining under these conditions (data not shown). 
The observation that cultures containing IL-1 $\beta$, IL- 6 and IL-21 had increased IL-17 expression following ROR $\gamma$ T transduction (Fig. 2a) suggested that an endogenous source of TGF- $\beta$ existed in our culture conditions, and that addition of the other cytokines relieved its effect in a similar manner to their effect following addition of exogenous TGF- $\beta$. Indeed TGF- $\beta$ is found in human and bovine serum 37,38 . Furthermore, serum TGF- $\beta$ was found to be sufficient to induce FOXP3 expression in naive human $\mathrm{CD}^{+} \mathrm{T}$ cells 39 . We thus asked whether IL-17 expression was increased in serum-free conditions. Cord blood $\mathrm{CD} 4^{+} \mathrm{T}$ cells were transduced with ROR $\gamma \mathrm{T}$ in serum-containing (RPMI-10\% FBS) and serum-free media. We observed a significant increase of IL-17 production in serum-free media, which was clearest when T cells had relatively little IL-17 following ROR $\gamma \mathrm{T}$ transduction in the presence of serum (Fig. 2d). Concurrently, FOXP3 expression was induced in serum-containing but not in serum-free medium. Following addition of a neutralizing anti-TGF- $\beta$ antibody in serum-containing medium, FOXP3 induction was almost abolished, while IL-17 expression was increased, but not to the extent observed in serum-free media. Higher concentration of neutralizing antibody did not improve IL-17 expression (Supplementary Fig. 3 online). These observations indicated that TGF- $\beta$ present in serum inhibits to some extent IL-17 expression induced by ROR $\gamma$ T and that other unidentified compounds contained in fetal bovine serum possibly also counteract $\mathrm{T}_{\mathrm{H}^{-}}-17$ cell differentiation. This prompted us to evaluate whether TGF- $\beta$, IL-1 $\beta$, IL- 6 and IL-21 would induce IL-17 production in serum-free media.

\section{Cytokines required for human $\mathrm{T}_{\mathrm{H}^{-1}}-17$ cell polarization}

Naive cord blood $\mathrm{CD} 4^{+} \mathrm{T}$ cells were activated with anti-CD3- and anti-CD28-coated beads in serum-free media in the presence of anti-IL-4 and anti-IFN- $\gamma$ alone or with various combinations of cytokines. These included increasing concentrations of TGF- $\beta$ with no added cytokine or with IL-1 $\beta$, IL-6 or IL-21, with or without IL-23 (Fig. 3a). After two weeks of culture, we could detect IL-17 expression by intracellular staining only in cells cultivated with a combination of TGF- $\beta$, IL- $1 \beta$ and IL-23. Although IL-2 was found to inhibit IL-17 expression in mice 40 , IL- $1 \beta$ relieved this effect 41 . We therefore tested the effect of IL- 2 and neutralizing anti-IL-2 in our culture conditions. In the presence of TGF- $\beta$, IL- $1 \beta$ and IL-23, IL-17 expression was increased at day 6 when IL-2 was included (Fig. 3b). Addition of an IL-2 blocking antibody prevented cell proliferation and IL-17 expression could not be detected. Thus IL-2 appears to have a positive effect on IL-17 expression in human $\mathrm{CD}^{+} \mathrm{T}$ cell culture. In the mouse, IL-23, IL-21 and IL-6 share the ability to activate STAT3 if their cognate receptors are expressed.

Although IL-6 and IL-21 with just TGF- $\beta$ failed to induce IL-17 in human cord blood T cells, they did induce IL-17 when IL-1 $\beta$ was included, albeit not as strongly as the combination of TGF- $\beta$, IL-23 and IL-1 $\beta$ (Fig. 3c). IL-21 is synthesized in response to IL- 6 by $\mathrm{T}_{\mathrm{H}^{-}} 17$ cells in the mouse and functions in an autocrine manner to induce $\mathrm{T}_{\mathrm{H}^{-}}-17$ cell differentiation 25-27. We therefore wished to determine if IL-21 or IL-6 were required for human IL-17 induction, as they are in mouse. In human cells, IL-6 and IL-21 were not induced by IL-1 $\beta+$ IL-23 + TGF- $\beta$ (Supplementary Fig. 4a,b online). Furthermore, addition of neutralizing anti-IL-6 antibody or soluble IL-21R had no effect on IL-17 expression at levels that inhibited STAT3 phosphorylation (Supplementary Fig. $4 \mathrm{c}$ and data not shown). Thus, in contrast to observations with naive mouse $\mathrm{CD} 4^{+} \mathrm{T}$ cells, IL-23 can participate in induction of IL-17 in human T cells in the absence of IL-6 and IL-21.

\section{Regulation of $\mathrm{T}_{\mathrm{H}}-17$ signature genes by TGF- $\beta$, IL-1 $\beta$ and IL-23}

Based on the results above we then used a combination of TGF- $\beta$, IL-1 $\beta$, IL-23, and IL-2 for $\mathrm{T}_{\mathrm{H}^{-1}} 17$ cell polarization of human cord blood naive $\mathrm{CD} 4^{+} \mathrm{T}$ cells. $\mathrm{IL}-17^{+}$cells were clearly detected as early as day 3 and increased up to day 6 in culture (Fig. 3d). Across multiple cord blood samples the proportion of IL- $17^{+}$cells obtained under these conditions ranged from $0.5 \%$ to $11 \%$ (Fig. 3e). As in the mouse 42, IL-17 induction was inhibited by addition of retinoic acid (Supplementary Fig. 5 online). We also evaluated IL-22 levels in $\mathrm{T}_{\mathrm{H}^{-}}-17$ cell differentiation 
cultures with cord blood cells. A substantial proportion of naive cord blood $\mathrm{CD} 4^{+} \mathrm{T}$ cells spontaneously expressed IL-22 protein after 6 days of culture (Fig. 3f); as the concentration of TGF- $\beta$ was increased, IL-22 expression was progressively inhibited.

Since we observed that ROR $\gamma \mathrm{T}$ induced expression of IL26, we asked whether IL26 could similarly be induced in human cord blood cells cultured under $\mathrm{T}_{\mathrm{H}^{-}} 17$ cell differentiation conditions. Under such conditions, IL17 mRNA expression was maximal in the presence of IL-1 $\beta$, IL-23 and TGF- $\beta$, consistent with the intracellular staining (Fig. 4a). IL26 expression was also detected and levels of IL26 mRNA increased with the dose of TGF- $\beta$ (Fig. 4b). Some expression of $I L 17 F$ was induced by IL-1 $\beta$ alone, but IL-23 alone had no effect (Fig. 4c). However, increasing concentrations of TGF- $\beta$ synergized with IL-23 and IL- $1 \beta$ to induce maximum $I L I 7 F$ expression. RORC expression was gradually induced with increasing concentrations of TGF- $\beta$ and was enhanced by further addition of both IL- $1 \beta$ and IL-23, but not either cytokine alone. In the same conditions, RORA expression was slightly induced by TGF- $\beta$ and there was no further effect upon addition of IL-1 $\beta$ and IL-23 (Supplementary Fig. 6a online). This observation is in agreement with the slight enrichment of RORA mRNA levels in memory CCR6 ${ }^{+}$cells compared to CCR6- cells (Supplementary Fig. 6b).

In mice, $I l 23 r$ is induced by IL- 6 or IL- 21 but inhibited by high concentrations of TGF- $\beta 43$. In human cells, IL23R expression was induced to some extent by IL-23 alone, but not IL-1 $\beta$, consistent with a previous report 28 (Fig. 4e). However, IL23R expression reached maximal levels in the presence of IL- $1 \beta$ and IL- 23 with increasing concentrations of TGF- $\beta$; this suggests that, in the presence of TGF- $\beta$ and IL-1 $\beta$, IL-23 induces expression of its own receptor through a positive feedback loop, leading to maximum expression and induction of RORC, ILI7 and $I L 17 F$. In addition, CCR6 cell surface expression was induced by TGF- $\beta$ alone (Fig 5a). Under $\mathrm{T}_{\mathrm{H}^{-}} 17$ differentiation conditions, IL-17 was detected only in the CCR6 ${ }^{+}$cells (Fig. 5b), consistent with what was observed in memory $\mathrm{T}_{\mathrm{H}^{-}} 17$ cells. TGF- $\beta$ also induced expression of FOXP3 in a dose-dependent manner (Fig. 5c). Addition of IL-23 as well as IL-6 and IL-21, but not IL-1 $\beta$, suppressed the induction of FOXP3 (Fig. $5 \mathrm{c}$ and data not shown). Thus, the regulation of FOXP3 expression during $\mathrm{T}_{\mathrm{H}^{-}} 17$ cell differentiation is similar in mouse and humans.

\section{Discussion}

Based on recent studies employing both in vitro culture systems and genetic approaches, it is now clear that TGF- $\beta$ acts in concert with the pro-inflammatory cytokines IL-6, IL-21, and IL-23 to induce the differentiation of $\mathrm{T}_{\mathrm{H}^{-}} 17$ cells in mice 20. Phosphorylation of STAT3 upon engagement of the inflammatory cytokine receptors 27,44 and induction of ROR $\gamma t$ expression are essential for murine $\mathrm{T}_{\mathrm{H}^{-}} 17$ cell differentiation21. The requirement for TGF- $\beta$ in $\mathrm{T}_{\mathrm{H}^{-}}-17$ cell differentiation was initially surprising, since it was known to act as an anti-inflammatory cytokine, at least in part through its induction and maintenance of regulatory $\mathrm{T}$ cells 22 . The function of TGF- $\beta$ may be dependent on context and thresholds, favoring $\mathrm{T}_{\mathrm{H}^{-1}} 17$ cell differentiation at low concentrations in the presence of inflammatory cytokines and $\mathrm{T}_{\text {reg }}$ cell differentiation at high concentrations 43 .

In light of the pivotal role for TGF- $\beta$ in controlling the balance between $\mathrm{T}_{\mathrm{H}^{-}} 17$ and $\mathrm{T}_{\text {reg }}$ cells balance in mice, it was unclear why it was found to be inhibitory in the induction of IL-17 in human $\mathrm{CD} 4^{+} \mathrm{T}$ cells with a naive surface phenotype 15,29. We have used serum-free medium to reveal that TGF- $\beta$ indeed has an essential role in the differentiation of naive human CD4 ${ }^{+}$ T cells towards the $\mathrm{T}_{\mathrm{H}^{-}} 17$ cell lineage, similar to what has been observed in mice. In human T cells, TGF- $\beta$ induced ROR $\gamma \mathrm{T}$ expression yet paradoxically inhibited its transcriptional activity, thus preventing expression of IL-17. A combination of IL-1 $\beta$ and IL-6, IL-21 or IL-23 relieved this inhibition and also contributed to ROR $\gamma \mathrm{T}$ expression, leading to induction of 
IL-17. Thus, similarly to the mouse, TGF- $\beta$ is required for IL-17 expression in human T cells and additional transcription factors induced by TCR stimulation, IL-1 $\beta$ and IL-6, IL-21 or IL-23 may be involved in inducing IL-17 expression 20.

We have shown a requirement for IL-23 for in vitro human $\mathrm{T}_{\mathrm{H}^{-}}-17$ cell differentiation, which contrasts with what has been observed in the mouse where IL-23 is required only in vivo 18 . However, with low concentrations of TGF- $\beta$ in mouse T cell culture, we found a positive effect of IL-23 on production of IL-17 43. Therefore, the discrepancy between the mouse and human systems with regards to IL-23 may be due to different culture conditions or different sensitivities to TGF- $\beta$. The inflammatory cytokines IL-6, IL-21 and IL-23 share signaling pathways by activating both STAT1 and STAT3 $45-49$, while IL- $1 \beta$ is thought to activate the kinases IRAK1 and IRAK2 through recruitment of the adaptor MyD88 50,51. Thus, STAT3 is likely to be a common denominator in the induction of ROR $\gamma \mathrm{T}$ and IL-17 expression in both species 20. The IL-1 pathway is important for the in vivo induction of $\mathrm{T}_{\mathrm{H}^{-}}-17$ cells in the mouse, but it does not appear to be required for polarization in vitro in the presence of serum 52,53. It remains to be determined whether an unrecognized requirement downstream of the IL-1 receptor is also needed during murine $\mathrm{T}_{\mathrm{H}^{-}} 17$ cell differentiation in vitro.

Previous observations showing inhibitory activity of TGF- $\beta$ in human $\mathrm{T}_{\mathrm{H}^{-}} 17$ cell differentiation was probably confounded by the use of serum and non-optimal naive cell purification 28,29 . Indeed, TGF- $\beta$ has long been recognized to be a 'switch' cytokine highly context- and concentration-dependent 54 . We revealed an essential effect of exogenous TGF$\beta$ in $\mathrm{T}_{\mathrm{H}^{-}} 17$ cell differentiation by using serum-free media, suggesting that TGF- $\beta$ present in serum might have masked this effect. However, neutralization of TGF- $\beta$ did not completely abolish the inhibitory effect of serum on ROR $\gamma$ T-directed IL-17 expression, and TGF- $\beta$ did not completely inhibit IL-17 expression following ROR $\gamma \mathrm{T}$ over-expression in serum-free conditions (data not shown). This indicates that yet unidentified inhibitory factors in the serum synergize with TGF- $\beta$ to counteract $\mathrm{T}_{\mathrm{H}^{-}} 17$ cell differentiation. In addition to $I L 17$, we have shown that $I L I 7 F$ and $I L 26$ are induced by ROR $\gamma \mathrm{T}$ overexpression and cytokine polarization. IL-26 has been shown to target epithelial cells and has been suggested to play a role in mucosal immunity 55, which is consistent with its induction in $\mathrm{T}_{\mathrm{H}^{-1}} 17$ cells. Rearrangements of the Il22-Ifng locus seem to have occurred in the mouse-rat lineage leading to a loss of Il26, but this cytokine may have a major role in host defense and inflammation in humans. Expression of IL-22 in human T cells was inhibited by TGF- $\beta$, similarly to what has been observed in the mouse 14 . While all $\mathrm{IL}-17^{+}$cells expressed CCR6 following $\mathrm{T}_{\mathrm{H}^{-}} 17$ cell differentiation, TGF$\beta$ alone induced CCR6. This is in agreement with the observation that $\mathrm{FOXP}^{+}$cells can also express CCR6 56. As expected, FOXP3 expression was induced by TGF- $\beta$ alone in serum-free conditions, and IL-6, IL-21 and IL-23 were each able to suppress the induction, as was also shown in mouse 20 . However, addition of IL- $1 \beta$ was required for the induction of IL-17 through a mechanism that is currently unknown.

In human memory cells expression of both IL-17 and IFN- $\gamma$ is often detected, which raises the question as to how such cells are derived. The polarization conditions described here for naive $\mathrm{T}$ cells results in the differentiation of only $\mathrm{IL}-17^{+} \mathrm{IFN}-\gamma^{-}$cells. Although we have not investigated why IFN- $\gamma$ fails to be expressed in these conditions, we believe that the high concentration of TGF- $\beta$ required for $\mathrm{T}_{\mathrm{H}^{-}} 17$ polarization most likely inhibits IFN- $\gamma$ expression. It remains to be determined whether under some conditions IL-17 and IFN- $\gamma$ can be coexpressed following differentiation of naive T cells. Functional plasticity has been observed in T helper cell differentiation 57. It is hence possible that either IL-17 or IFN- $\gamma$ is expressed in response to diverse stimuli received by previously differentiated $\mathrm{T}_{\mathrm{H}} 1$ or $\mathrm{T}_{\mathrm{H}^{-}} 17$ memory cells, respectively. 
We previously showed that the orphan nuclear receptor ROR $\gamma$ is uniquely expressed in mouse $\mathrm{T}$ cells that produce IL-17 and is required for up-regulation of this cytokine in T cells both in vivo and in vitro 21 . Here we have shown that $\mathrm{ROR} \gamma \mathrm{T}$ also has a central role in human $\mathrm{T}_{\mathrm{H}^{-}}-17$ cell differentiation. shRNA 'knock-down' of ROR $\gamma \mathrm{T}$ in memory CCR6 ${ }^{+}$cells resulted in marked reduction of IL-17 expression, indicating that the nuclear receptor is required for maintenance of cytokine production in $\mathrm{T}_{\mathrm{H}^{-}} 17$ cells. This result does not rule out a small contribution in directing IL-17 expression by the closely related paralogue ROR $\alpha$, which was shown to have a similar role in mouse 58 . However, we did not observe a strong enrichment of RORA mRNA in $\mathrm{CCR}^{+}$cells compared to $\mathrm{CCR}^{-}$cells. Furthermore, RORA mRNA was not strongly induced by a combination of IL- $1 \beta$, IL-23 and TGF- $\beta$ that otherwise induced a 50 -fold increase of $R O R C \mathrm{mRNA}$. However, four differentially spliced isoforms of $R O R A$ have been described and their respective transcriptional regulation has not been determined. Furthermore, our data do not exclude potential post-transcriptional regulation of ROR $\alpha$. Finally, the ability of ROR $\beta$ to induce IL-17 expression needs to be evaluated in relevant cell types, since ROR $\beta$ expression has not been detected in peripheral $\mathrm{CD} 4^{+} \mathrm{T}$ cells (data not shown).

The IL-23- $\mathrm{T}_{\mathrm{H}^{-}}-17$ axis has recently been implicated in multiple human diseases 59 . Our demonstration of a requirement for IL-23 in the differentiation of $\mathrm{T}_{\mathrm{H}^{-}}-17$ cells is relevant in light of multiple polymorphisms in the human $I L 23 R$ gene that have been reported to be associated with Crohn's disease and psoriasis 19,60-64. It will be important to elucidate the roles of IL-1 $\beta$, IL-6, IL-21, IL-23 and TGF- $\beta$ in the pathogenesis of human diseases involving $\mathrm{T}_{\mathrm{H}^{-}} 17$ cells. Importantly, the participation of TGF- $\beta$ in the induction of $\mathrm{T}_{\mathrm{H}^{-}}-17$ and $\mathrm{T}_{\text {reg }}$ cells will likely be critical in maintenance of immune system homeostasis, particularly at mucosal surfaces, and imbalance in this system may result in autoimmunity. In this context, our results offer a working model for the study of human $\mathrm{T}_{\mathrm{H}^{-}} 17$ cell differentiation and provide new opportunities for manipulating these cells in inflammatory diseases.

\section{Materials and Methods}

\section{Cell purification}

Blood samples were obtained from the New York Blood Center. Mononuclear cells were prepared from buffy coats of healthy adult donors or from cord blood on FicollPAQUE gradients. $\mathrm{CD} 4^{+} \mathrm{T}$ cells were isolated on an autoMACS Pro using Miltenyi bead depletion of $\mathrm{CD} 14^{+}$and $\mathrm{CD} 25^{+}$cells followed by positive selection of $\mathrm{CD} 4^{+}$cells. Cord blood $\mathrm{CD} 4^{+} \mathrm{T}$ cells were $>97 \%$ pure and $100 \% \mathrm{CD}^{2} 5 \mathrm{RA}^{+}$and were used as such for initial transduction experiments. Adult $\mathrm{CD} 4^{+} \mathrm{T}$ cell subsets and naive cord blood $\mathrm{CD} 4^{+} \mathrm{T}$ cells were further purified respectively as $\mathrm{CD} 3{ }^{+} \mathrm{CD} 4{ }^{+} \mathrm{CD} 25^{-} \mathrm{CD} 45 \mathrm{RO}^{-/+}$and $\mathrm{CD} 3{ }^{+} \mathrm{CD} 4{ }^{+} \mathrm{CD} 25^{-} \mathrm{HLA}-$ $\mathrm{DR}^{-} \mathrm{CD} 45 \mathrm{RA}^{+}$by cell sorting on a FACSAria.

\section{Cell Culture and Lentiviral Transduction}

Cells were cultivated in either RPMI1640 (Invitrogen) supplemented with 10\% fetal bovine serum (Hyclone), penicillin-streptomycin, $2 \mathrm{mM}$ glutamine, $10 \mathrm{mM}$ HEPES, $1 \mathrm{mM}$ pyruvate and $0.1 \mathrm{mM}$ nonessential amino acids or serum-free XVIVO-20 (Lonza) supplemented with penicillin-streptomycin in a $37^{\circ} \mathrm{C} 5 \% \mathrm{CO}_{2}$ incubator. $\mathrm{CD} 4^{+} \mathrm{T}$ cells were stimulated by addition of anti-mouse IgG magnetic beads (Pierce) previously coated with purified anti-CD3 and antiCD28 at final concentrations of $1 \mathrm{bead} / \mathrm{cell}$ and $1 \mu \mathrm{g} / \mathrm{ml}$ of each antibody. For transduction experiments, cells were seeded at a concentration of $10^{6}$ cells $/ \mathrm{ml}$ in 24 well plates with anti$\mathrm{CD} 3 / \mathrm{CD} 28$ coated beads, $10 \mu \mathrm{g} / \mathrm{ml}$ polybrene and $10 \mathrm{U} / \mathrm{ml} \mathrm{IL-2}$ at day 0 . Lentiviral supernatants were added at an MOI ranging from 1 to 10 . Cells were washed at day 1 and split as needed in the presence of IL-2. For the shRNA experiment, puromycin was added at day 2 at $2 \mu \mathrm{g} / \mathrm{ml}$. For polarization experiments, cells were seeded at a concentration of $5 \times 10^{5}$ to 
$10^{6}$ cells $/ \mathrm{ml}$ in U-bottom 96 well plates with anti-CD3 + anti-CD28 coated beads. IL-2 at 10 $\mathrm{U} / \mathrm{ml}$ was either added at day 0 or day 3 . Media was replaced at day 3 and cells were split in the presence of IL-2. For long-term experiments, cells were split as needed. In some cases, 10 $\mathrm{ng} / \mathrm{ml} \mathrm{IL-1 \beta}$ (eBioscience), $10 \mathrm{ng} / \mathrm{ml} \mathrm{IL-6} \mathrm{(eBioscience),} 10 \mathrm{ng} / \mathrm{ml}$ IL-21 (Cell Sciences), 10 ng/ml IL-23 (eBioscience), $10 \mathrm{ng} / \mathrm{ml}$ TNF- $\alpha$ (eBioscience), $10 \mathrm{ng} / \mathrm{ml}$ IL-4 (eBioscience), various concentrations of TGF- $\beta 1$ (PeproTech), neutralizing soluble IL-21R (R\&D) and neutralizing antibodies against IL-2, IL-4, IL-6, IFN- $\gamma$ or TGF- $\beta(1 \mu \mathrm{g} / \mathrm{ml}$ except where noted otherwise; see supplementary table 1 for details) were added at day 0 and maintained throughout the experiment. Cells were harvested at day 6 for intracellular staining and realtime PCR analysis except where specified otherwise.

\section{Surface and Intracellular Staining}

For intracellular cytokine staining, cells were incubated for 5 hours with $50 \mathrm{ng} / \mathrm{ml}$ PMA (Sigma), $500 \mathrm{ng} / \mathrm{ml}$ Ionomycin (Sigma), and GolgiStop (BD). Surface staining was performed by incubation with the corresponding fluorescently labeled antibodies for $15 \mathrm{~min}$ on ice. Intracellular staining was performed using the Cytofix-Cytoperm buffer set (BD). Briefly, cells were fixed and permeabilized for $30 \mathrm{~min}$ at room temperature and stained in permeabilization buffer for $30 \mathrm{~min}$ at room temperature. Flow cytometric measures were performed on a LSR II (BD Biosciences) instrument and analyzed using FlowJo software (Tree Star Inc.).

Antibodies are detailed in Supplementary Table 1 online. FOXP3 was stained using FOXP3 staining buffers (eBioscience). We used the FJK-16s antibody, originally reported as an antimouse/rat FoxP3 antibody. Indeed we have observed that unlike most human FOXP3 antibodies available this antibody robustly stains endogenous and overexpressed human fulllength FOXP3 (data not shown).

\section{Plasmids and Lentiviral Production}

The gene for human ROR $\gamma$ T was cloned from human thymus. A double FLAG tag (DFTC) was added at the $\mathrm{N}$-terminus. The gene for human ROR $\alpha$ isoform d was cloned from peripheral $\mathrm{CD}^{+} \mathrm{T}$ cells, while the gene for human ROR $\beta$ was cloned from U937 cells. cDNAs were cloned in an HIV-derived vector HDV-IRES-HSA or HDV-IRES-GFP 65. Human GATA-3and T-bet-expressing lentiviral vectors have been previously described 57 . Short hairpin RNA (shRNA)-expressing vectors were obtained from OpenBiosystems. shRNA-1 is TRCN33657 (target sequence TCTGCAAGACTCATCGCCAAA) and shRNA-2 is TRCN33658 (target sequence CGAGGATGAGATTGCCCTCTA), and pLKO.1puro was used as control. Viral supernatants were produced by transient transfection of HEK293T cells with a combination of a shRNA vector, a VSV-G expression plasmid and the packaging plasmid pCMV $\Delta$ R8.9. Viral particles were concentrated by ultracentrifugation at $25,000 \mathrm{rpm}$ for $2 \mathrm{~h}$ at $4{ }^{\circ} \mathrm{C}$, resuspended in PBS containing $1 \% \mathrm{BSA}$, aliquoted and frozen.

\section{Real-time PCR}

RNA was extracted by TRIZOL (Invitrogen) and cDNA was synthesized with Superscript II (Invitrogen) and random primers. cDNA was analyzed by real-time quantitative PCR in triplicates by using iQ CYBR Green Supermix (Bio-Rad) or QuantiTect Multiplex PCR mix (Qiagen) in the iCycler Sequence Detection System (Bio-Rad). The starting quantity (SQ) of the initial cDNA sample was calculated from primer-specific standard curves by using the iCycler Data Analysis Software. The expression level of each gene was normalized to ACTB expression level using the standard curve method. Fold changes were calculated by normalizing to the first sample of each set. Error bars were calculated based on triplicate measurements of each gene. The primer sets for real-time PCR are detailed in Supplementary Table 2 online. 


\section{Supplementary Material}

Refer to Web version on PubMed Central for supplementary material.

\section{Acknowledgements}

We would like to thank the New York Cord Blood Center for providing us with samples; Naomi Taylor for suggestions; Liang Zhou and Ivaylo I. Ivanov for critical reading of the manuscript; and Xing Gong, Tamika Jones and Changsoo Kwak for technical assistance. N.M. was supported by an EMBO long term fellowship and a fellowship from the Irvington Institute Fellowship Program of the Cancer Research Institute. D.R.L. is an Investigator of the Howard Hughes Medical Institute. This was work was supported by NIH grant 5 R37 AI033303 to D.R.L. and by NIH grant R01 AI065303 to D.U..

\section{References}

1. Weaver CT, Hatton RD, Mangan PR, Harrington LE. IL-17 family cytokines and the expanding diversity of effector T cell lineages. Annual review of immunology 2007;25:821-852.

2. Bettelli E, Korn T, Kuchroo VK. Th17: the third member of the effector T cell trilogy. Current opinion in immunology 2007;19:652-657. [PubMed: 17766098]

3. Stockinger B, Veldhoen M. Differentiation and function of Th17 T cells. Current opinion in immunology 2007;19:281-286. [PubMed: 17433650]

4. Acosta-Rodriguez EV, et al. Surface phenotype and antigenic specificity of human interleukin 17producing T helper memory cells. Nature immunology 2007;8:639-646. [PubMed: 17486092]

5. Annunziato F, et al. Phenotypic and functional features of human Th17 cells. J Exp Med 2007;204:1849-1861. [PubMed: 17635957]

6. Lock C, et al. Gene-microarray analysis of multiple sclerosis lesions yields new targets validated in autoimmune encephalomyelitis. Nat Med 2002;8:500-508. [PubMed: 11984595]

7. Matusevicius D, et al. Interleukin-17 mRNA expression in blood and CSF mononuclear cells is augmented in multiple sclerosis. Mult Scler 1999;5:101-104. [PubMed: 10335518]

8. Tzartos JS, et al. Interleukin-17 production in central nervous system-infiltrating T cells and glial cells is associated with active disease in multiple sclerosis. Am J Pathol 2008;172:146-155. [PubMed: 18156204]

9. Kebir H, et al. Human $\mathrm{T}(\mathrm{H}) 17$ lymphocytes promote blood-brain barrier disruption and central nervous system inflammation. Nat Med 2007;13:1173-1175. [PubMed: 17828272]

10. Chabaud M, et al. Human interleukin-17: A T cell-derived proinflammatory cytokine produced by the rheumatoid synovium. Arthritis Rheum 1999;42:963-970. [PubMed: 10323452]

11. Attur MG, Patel RN, Abramson SB, Amin AR. Interleukin-17 up-regulation of nitric oxide production in human osteoarthritis cartilage. Arthritis Rheum 1997;40:1050-1053. [PubMed: 9182915]

12. Fossiez F, et al. T cell interleukin-17 induces stromal cells to produce proinflammatory and hematopoietic cytokines. J Exp Med 1996;183:2593-2603. [PubMed: 8676080]

13. Homey B, et al. Up-regulation of macrophage inflammatory protein-3 alpha/CCL20 and CC chemokine receptor 6 in psoriasis. J Immunol 2000;164:6621-6632. [PubMed: 10843722]

14. Zheng Y, et al. Interleukin-22, a T(H)17 cytokine, mediates IL-23-induced dermal inflammation and acanthosis. Nature 2007;445:648-651. [PubMed: 17187052]

15. Wilson NJ, et al. Development, cytokine profile and function of human interleukin 17-producing helper T cells. Nature immunology 2007;8:950-957. [PubMed: 17676044]

16. Annunziato F, et al. Phenotypic and functional features of human Th17 cells. J Exp Med 2007;204:1849-1861. [PubMed: 17635957]

17. Becker $\mathrm{C}$, et al. Constitutive $\mathrm{p} 40$ promoter activation and IL-23 production in the terminal ileum mediated by dendritic cells. The Journal of clinical investigation 2003;112:693-706. [PubMed: 12952918]

18. McGeachy MJ, et al. TGF-beta and IL- 6 drive the production of IL-17 and IL-10 by T cells and restrain T(H)-17 cell-mediated pathology. Nature immunology 2007;8:1390-1397. [PubMed: 17994024] 
19. Duerr RH, et al. A genome-wide association study identifies IL23R as an inflammatory bowel disease gene. Science 2006;314:1461-1463. [PubMed: 17068223]

20. Ivanov II, Zhou L, Littman DR. Transcriptional regulation of Th17 cell differentiation. Semin Immunol. 2007

21. Ivanov II, et al. The orphan nuclear receptor RORgammat directs the differentiation program of proinflammatory IL-17+ T helper cells. Cell 2006;126:1121-1133. [PubMed: 16990136]

22. Veldhoen M, Hocking RJ, Atkins CJ, Locksley RM, Stockinger B. TGFbeta in the context of an inflammatory cytokine milieu supports de novo differentiation of IL-17-producing T cells. Immunity 2006;24:179-189. [PubMed: 16473830]

23. Bettelli E, et al. Reciprocal developmental pathways for the generation of pathogenic effector TH17 and regulatory T cells. Nature 2006;441:235-238. [PubMed: 16648838]

24. Mangan PR, et al. Transforming growth factor-beta induces development of the $\mathrm{T}(\mathrm{H}) 17$ lineage. Nature 2006;441:231-234. [PubMed: 16648837]

25. Korn T, et al. IL-21 initiates an alternative pathway to induce proinflammatory $\mathrm{T}(\mathrm{H}) 17$ cells. Nature 2007;448:484-487. [PubMed: 17581588]

26. Nurieva R, et al. Essential autocrine regulation by IL-21 in the generation of inflammatory T cells. Nature 2007;448:480-483. [PubMed: 17581589]

27. Zhou L, et al. IL-6 programs T(H)-17 cell differentiation by promoting sequential engagement of the IL-21 and IL-23 pathways. Nature immunology 2007;8:967-974. [PubMed: 17581537]

28. Chen Z, Tato CM, Muul L, Laurence A, O'Shea JJ. Distinct regulation of interleukin-17 in human T helper lymphocytes. Arthritis Rheum 2007;56:2936-2946. [PubMed: 17763419]

29. Acosta-Rodriguez EV, Napolitani G, Lanzavecchia A, Sallusto F. Interleukins 1beta and 6 but not transforming growth factor-beta are essential for the differentiation of interleukin 17-producing human T helper cells. Nature immunology 2007;8:942-949. [PubMed: 17676045]

30. van Beelen AJ, et al. Stimulation of the intracellular bacterial sensor NOD2 programs dendritic cells to promote interleukin-17 production in human memory T cells. Immunity 2007;27:660-669.

[PubMed: 17919942]

31. Evans HG, Suddason T, Jackson I, Taams LS, Lord GM. Optimal induction of T helper 17 cells in humans requires T cell receptor ligation in the context of Toll-like receptor-activated monocytes. Proc Natl Acad Sci U S A 2007;104:17034-17039. [PubMed: 17942669]

32. Stockinger B, Veldhoen M, Martin B. Th17 T cells: Linking innate and adaptive immunity. Semin Immunol. 2007

33. De Rosa SC, Herzenberg LA, Herzenberg LA, Roederer M. 11-color, 13-parameter flow cytometry: identification of human naive T cells by phenotype, function, and T-cell receptor diversity. Nat Med 2001;7:245-248. [PubMed: 11175858]

34. Laurence A, O'shea JJ. TH-17 differentiation: of mice and men. Nature immunology 2007;8:903905. [PubMed: 17712339]

35. Igawa D, Sakai M, Savan R. An unexpected discovery of two interferon gamma-like genes along with interleukin (IL)-22 and -26 from teleost: IL-22 and -26 genes have been described for the first time outside mammals. Mol Immunol 2006;43:999-1009. [PubMed: 16005068]

36. Sato W, Aranami T, Yamamura T. Cutting edge: Human Th17 cells are identified as bearing CCR2 +CCR5- phenotype. J Immunol 2007;178:7525-7529. [PubMed: 17548586]

37. Kyrtsonis MC, et al. Serum transforming growth factor-beta 1 is related to the degree of immunoparesis in patients with multiple myeloma. Med Oncol 1998;15:124-128. [PubMed: 9789221]

38. Wight M. TGF-beta1 in bovine serum. Art Sci 2001;19:1-3.

39. Tran DQ, Ramsey H, Shevach EM. Induction of FOXP3 expression in naive human CD4+FOXP3 T cells by T-cell receptor stimulation is transforming growth factor- $\{$ beta $\}$ dependent but does not confer a regulatory phenotype. Blood 2007;110:2983-2990. [PubMed: 17644734]

40. Laurence A, et al. Interleukin-2 signaling via STAT5 constrains T helper 17 cell generation. Immunity 2007;26:371-381. [PubMed: 17363300] 
41. Kryczek I, et al. Cutting edge: opposite effects of IL-1 and IL-2 on the regulation of IL-17+ T cell pool IL-1 subverts IL-2-mediated suppression. J Immunol 2007;179:1423-1426. [PubMed: 17641006]

42. Mucida D, et al. Reciprocal TH17 and regulatory T cell differentiation mediated by retinoic acid. Science 2007;317:256-260. [PubMed: 17569825]

43. Zhou L, et al. TGF-beta-induced Foxp3 inhibits Th17 cell differentiation by antagonizing RORgammat function. Nature. 2008Accepted

44. Wei L, Laurence A, Elias KM, O'Shea JJ. IL-21 is produced by Th17 cells and drives IL-17 production in a STAT3-dependent manner. J Biol Chem 2007;282:34605-34610. [PubMed: 17884812]

45. Parham C, et al. A receptor for the heterodimeric cytokine IL-23 is composed of IL-12Rbeta1 and a novel cytokine receptor subunit, IL-23R. J Immunol 2002;168:5699-5708. [PubMed: 12023369]

46. Habib T, Senadheera S, Weinberg K, Kaushansky K. The common gamma chain (gamma c) is a required signaling component of the IL-21 receptor and supports IL-21-induced cell proliferation via JAK3. Biochemistry 2002;41:8725-8731. [PubMed: 12093291]

47. Asao H, et al. Cutting edge: the common gamma-chain is an indispensable subunit of the IL-21 receptor complex. J Immunol 2001;167:1-5. [PubMed: 11418623]

48. Gerhartz C, et al. Differential activation of acute phase response factor/STAT3 and STAT1 via the cytoplasmic domain of the interleukin 6 signal transducer gp130. I. Definition of a novel phosphotyrosine motif mediating STAT1 activation. J Biol Chem 1996;271:12991-12998. [PubMed: 8662591]

49. Stahl N, et al. Choice of STATs and other substrates specified by modular tyrosine-based motifs in cytokine receptors. Science 1995;267:1349-1353. [PubMed: 7871433]

50. Muzio M, Ni J, Feng P, Dixit VM. IRAK (Pelle) family member IRAK-2 and MyD88 as proximal mediators of IL-1 signaling. Science 1997;278:1612-1615. [PubMed: 9374458]

51. Wesche H, Henzel WJ, Shillinglaw W, Li S, Cao Z. MyD88: an adapter that recruits IRAK to the IL-1 receptor complex. Immunity 1997;7:837-847. [PubMed: 9430229]

52. Cho ML, et al. STAT3 and NF-kappaB signal pathway is required for IL-23-mediated IL-17 production in spontaneous arthritis animal model IL-1 receptor antagonist-deficient mice. J Immunol 2006;176:5652-5661. [PubMed: 16622035]

53. Sutton C, Brereton C, Keogh B, Mills KH, Lavelle EC. A crucial role for interleukin (IL)-1 in the induction of IL-17-producing T cells that mediate autoimmune encephalomyelitis. J Exp Med 2006;203:1685-1691. [PubMed: 16818675]

54. Sporn MB, Roberts AB. TGF-beta: problems and prospects. Cell Regul 1990;1:875-882. [PubMed: 2100192]

55. Hor S, Pirzer H, Dumoutier L, Bauer F, Wittmann S. The T-cell Lymphokine Interleukin-26 Targets Epithelial Cells through the Interleukin-20 Receptor 1 .... Journal of Biological Chemistry. 2004

56. Lim HW, Lee J, Hillsamer P, Kim CH. Human Th17 cells share major trafficking receptors with both polarized effector T cells and FOXP3+ regulatory T cells. J Immunol 2008;180:122-129. [PubMed: 18097011]

57. Sundrud MS, et al. Genetic reprogramming of primary human T cells reveals functional plasticity in Th cell differentiation. J Immunol 2003;171:3542-3549. [PubMed: 14500650]

58. Yang XO, et al. T Helper 17 Lineage Differentiation Is Programmed by Orphan Nuclear Receptors RORalpha and RORgamma. Immunity. 2007

59. Kikly K, Liu L, Na S, Sedgwick JD. The IL-23/Th(17) axis: therapeutic targets for autoimmune inflammation. Current opinion in immunology 2006;18:670-675. [PubMed: 17010592]

60. Dubinsky MC, et al. IL-23 receptor (IL-23R) gene protects against pediatric Crohn's disease. Inflamm Bowel Dis 2007;13:511-515. [PubMed: 17309073]

61. Oliver J, Rueda B, Lopez-Nevot MA, Gomez-Garcia M, Martin J. Replication of an association between IL23R gene polymorphism with inflammatory bowel disease. Clin Gastroenterol Hepatol 2007;5:977-981. 981, e971-972. [PubMed: 17678845]

62. Smith RL, et al. Polymorphisms in the IL-12beta and IL-23R Genes Are Associated with Psoriasis of Early Onset in a UK Cohort. J Invest Dermatol. 2007 
63. Baldassano RN, et al. Association of variants of the interleukin-23 receptor gene with susceptibility to pediatric Crohn's disease. Clin Gastroenterol Hepatol 2007;5:972-976. [PubMed: 17618837]

64. Glas J, et al. rs1004819 is the main disease-associated IL23R variant in German Crohn's disease patients: combined analysis of IL23R, CARD15, and OCTN1/2 variants. PLoS ONE 2007;2:e819. [PubMed: 17786191]

65. Unutmaz D, KewalRamani VN, Marmon S, Littman DR. Cytokine signals are sufficient for HIV-1 infection of resting human T lymphocytes. J Exp Med 1999;189:1735-1746. [PubMed: 10359577] 


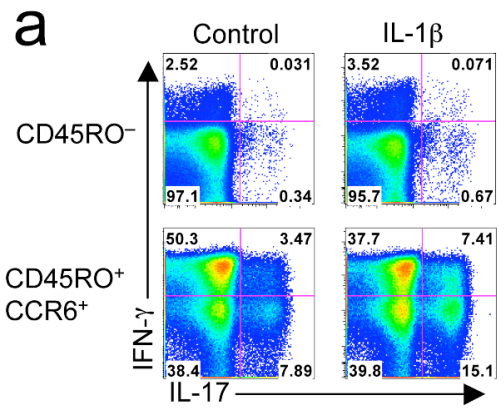

b

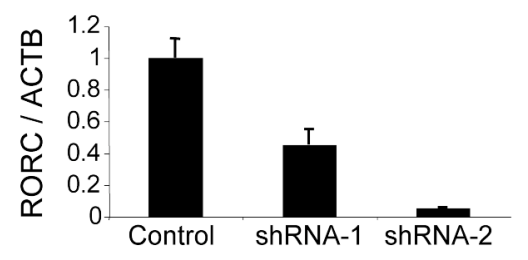

C

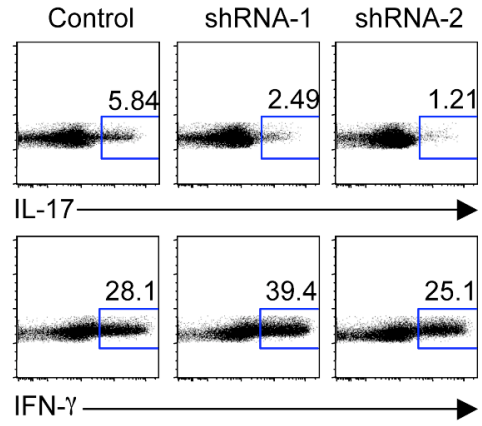

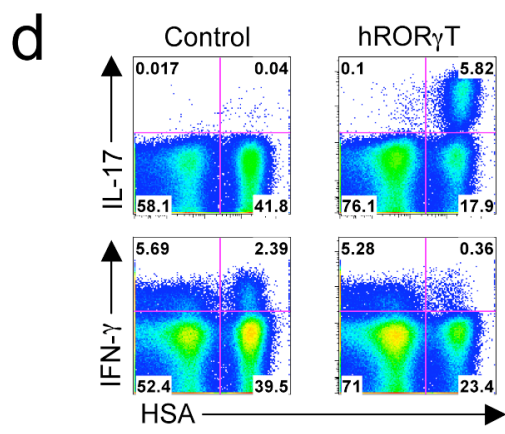

e
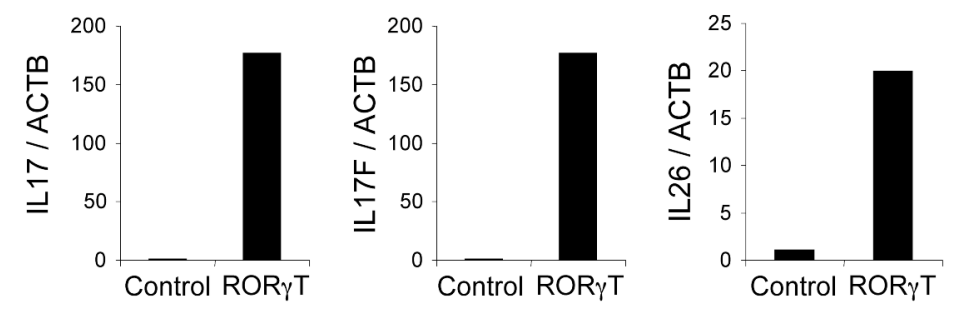

f

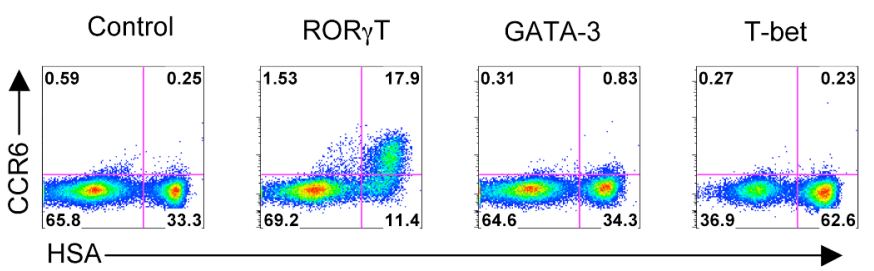

Figure 1. ROR $\gamma \mathrm{T}$ is necessary and sufficient for the expression of IL-17 in human $\mathrm{CD4}^{+} \mathrm{T}$ cells (a) Flow cytometry on sorted $\mathrm{CD}_{4} 5 \mathrm{RO}^{-}$and $\mathrm{CD}_{4} 4 \mathrm{RO}^{+} \mathrm{CCR} 6^{+}$activated and expanded in the presence of IL-2 with or without IL-1 $\beta$. IL-17 and IFN- $\gamma$ production was analyzed at day 6 . (b,c) RT-PCR for RORC and ACTB mRNA expression (b) and flow cytometry for intracellular IL-17 and IFN- $\gamma(\mathbf{c})$ in sorted CD45RO ${ }^{+} \mathrm{CCR} 6{ }^{+}$cells transduced with an empty vector or vector encoding for ROR $\gamma$ T-specific shRNA (shRNA-1 and shRNA-2). Cells were selected in puromycin at day 2 and expression of mRNA and cytokines was analyzed at day 6. Data are representative of four independent experiments. (d) Flow cytometry of naive cord blood $\mathrm{CD}^{+}{ }^{+} \mathrm{T}$ cells activated, transduced by vectors encoding IRES-HSA or ROR $\gamma \mathrm{T}-\mathrm{IRES}-\mathrm{HSA}$ and then expanded for 6 days in the presence of IL-2. Intracellular IL-17 and IFN- $\gamma$ production was analyzed at day 6. (e) RT-PCR of ACTB, IL17, IL17F and IL26 in naive cord blood CD4 ${ }^{+} \mathrm{T}$ cells transduced with vectors encoding IRES-GFP or ROR $\gamma$ T-IRES-GFP. GFP ${ }^{+}$cells were sorted at day 6 and the levels of mRNAs were analyzed. (f) Flow cytometry of naive cord blood $\mathrm{CD}^{+} \mathrm{T}$ cells transduced with vectors encoding IRES-HSA, ROR $\gamma$ T-IRES-HSA, GATA-3IRES-HSA or T-bet-IRES-HSA. CCR6 cell surface expression was measured at day 12. Each panel is representative of three independent experiments unless noted otherwise. 
a

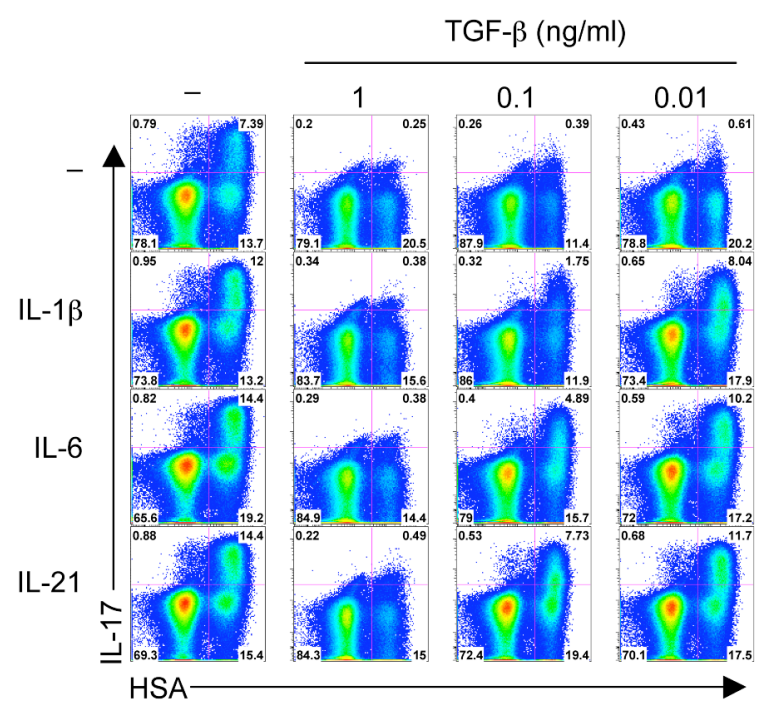

b

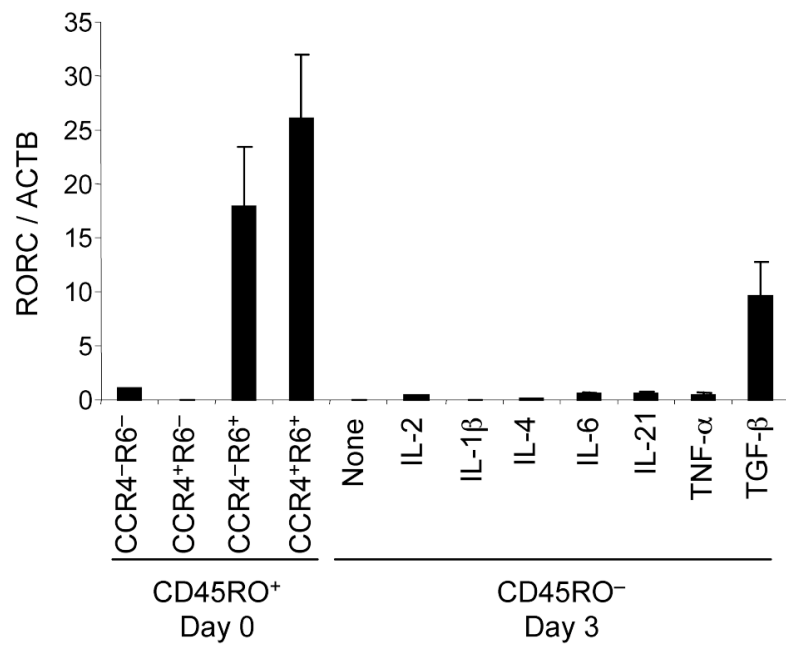

C

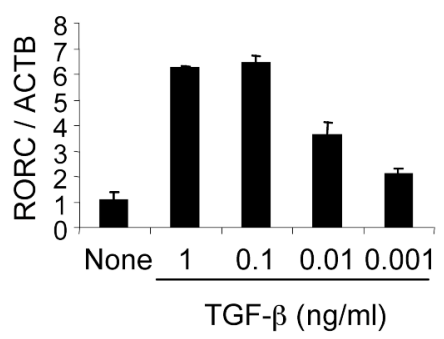

d

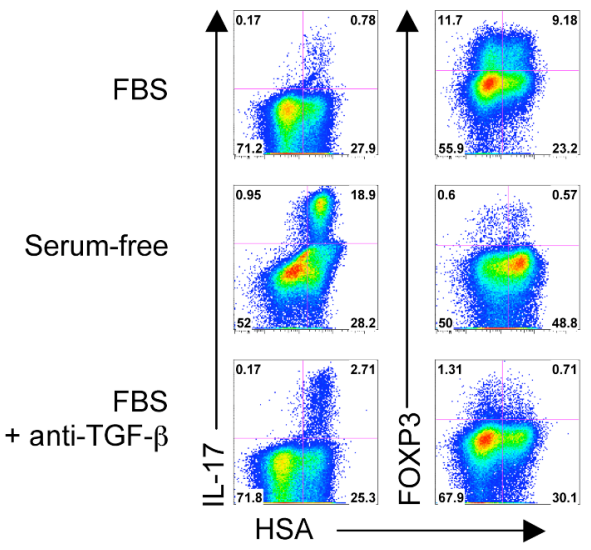

Figure 2. TGF- $\beta$ induces ROR $\gamma$ T and inhibits its activity, but the inhibition is relieved by inflammatory cytokines

(a) Flow cytometry of naive cord blood $\mathrm{CD} 4^{+} \mathrm{T}$ cells transduced with a vector encoding ROR $\gamma$ T-IRES-HSA alone or with combination of IL-1 $\beta$, IL-6, IL-21 and increasing concentrations of TGF- $\beta$. IL-17 intracellular staining was performed at day 6 . (b,c) RT-PCR of $R O R C$ and $A C T B$ expression measured in freshly sorted $\mathrm{CCR} 4^{-/+} \mathrm{CCR} 6^{-/+}$adult memory $\mathrm{CD} 4^{+} \mathrm{T}$ cells and in naive $\mathrm{CD} 4^{+} \mathrm{T}$ cells cultivated for 3 days in the presence of various cytokines (b) and in naive cord blood $\mathrm{CD}^{+} \mathrm{T}$ cells cultivated with various concentrations of TGF- $\beta$ (c) (d) Flow cytometry of naive cord blood CD4 ${ }^{+} \mathrm{T}$ cells transduced with a vector encoding ROR $\gamma$ T-IRES-HSA in serum-containing medium with or without anti-TGF- $\beta$ or in serum-free medium. Intracellular IL-17 and FOXP3 expression was analyzed at day 6. A representative donor with low IL-17 expression following ROR $\gamma \mathrm{T}$ transduction in the presence of serum is shown. Each panel is representative of at least three independent experiments. 
a

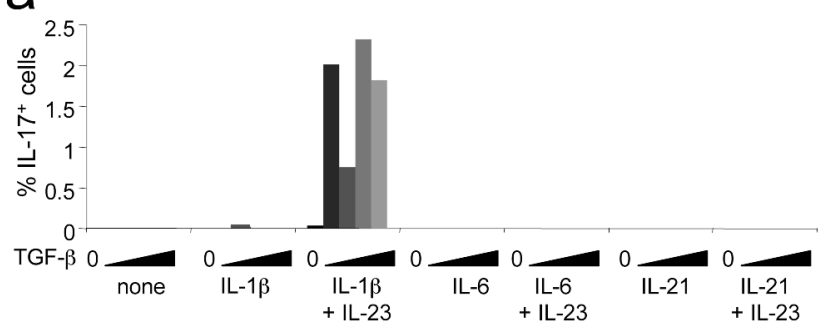

b

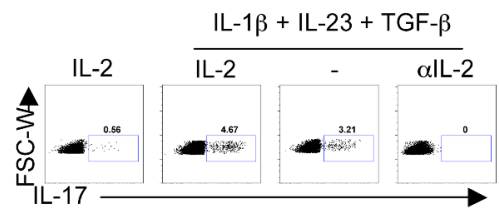

C

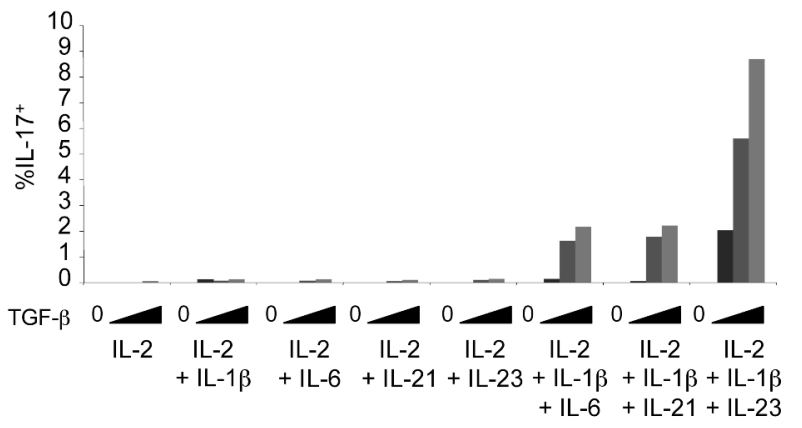

d

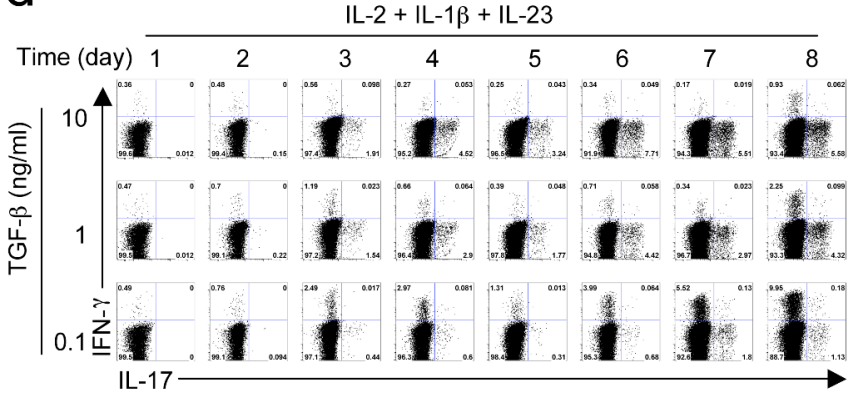

e

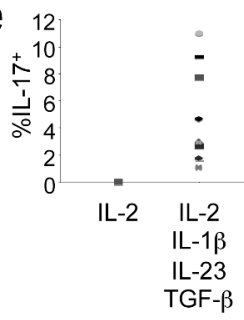

$f$

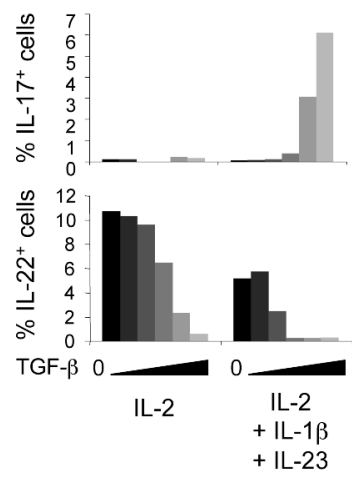

Figure 3. TGF- $\beta$, IL-1 $\beta$ and IL-6, IL-21 or IL-23 are required for human $T_{H^{-17}}$ cell polarization in serum-free conditions

(a) Naive cord blood CD4 ${ }^{+} \mathrm{T}$ cells were activated without cytokines or with IL-1 $\beta$, IL-6 or IL-21 with or without IL-23, alone or with increasing concentrations of TGF- $\beta$. IL-2 was added at day 3 and IL-17 expression was analyzed at day 14. (b) Naive cord blood CD4 ${ }^{+}$T cells were activated with no cytokine or with a combination of IL- $1 \beta+\mathrm{IL}-23+\mathrm{TGF}-\beta(1 \mathrm{ng} / \mathrm{ml})$, with or without $10 \mathrm{U} / \mathrm{ml}$ IL-2 or neutralizing anti-IL-2. IL-17 expression was analyzed at day 6 .

(c) Naive cord blood CD4 ${ }^{+} \mathrm{T}$ cells were cultivated with IL-2 and different concentrations of TGF- $\beta$ in the presence of the listed cytokines. IL-17 expression was analyzed at day 6 . (d) Time-course of IL-17 and IFN- $\gamma$ production in naive cord blood CD4 ${ }^{+} \mathrm{T}$ cells polarized in the presence of IL- $2+$ IL-1 $\beta+$ IL-23 + TGF- $\beta(0.1,1$ or $10 \mathrm{ng} / \mathrm{ml})$. (e) Summary of IL-17 expression in day 6 cultures of naive cord blood $\mathrm{CD}^{+} \mathrm{T}$ cells from different donors $(n=11)$ in the presence of IL- $2+$ IL- $1 \beta+$ IL- $23+10 \mathrm{ng} / \mathrm{ml}$ TGF- $\beta$. (f) Naive cord blood CD4 ${ }^{+} \mathrm{T}$ cells were cultivated in IL-2 alone or IL- $23+$ IL-1 $\beta+$ IL-2 with increasing concentrations of TGF$\beta$. IL-17 and IL-22 expression were analyzed at day 6 . Each panel is representative of at least three independent donors. 

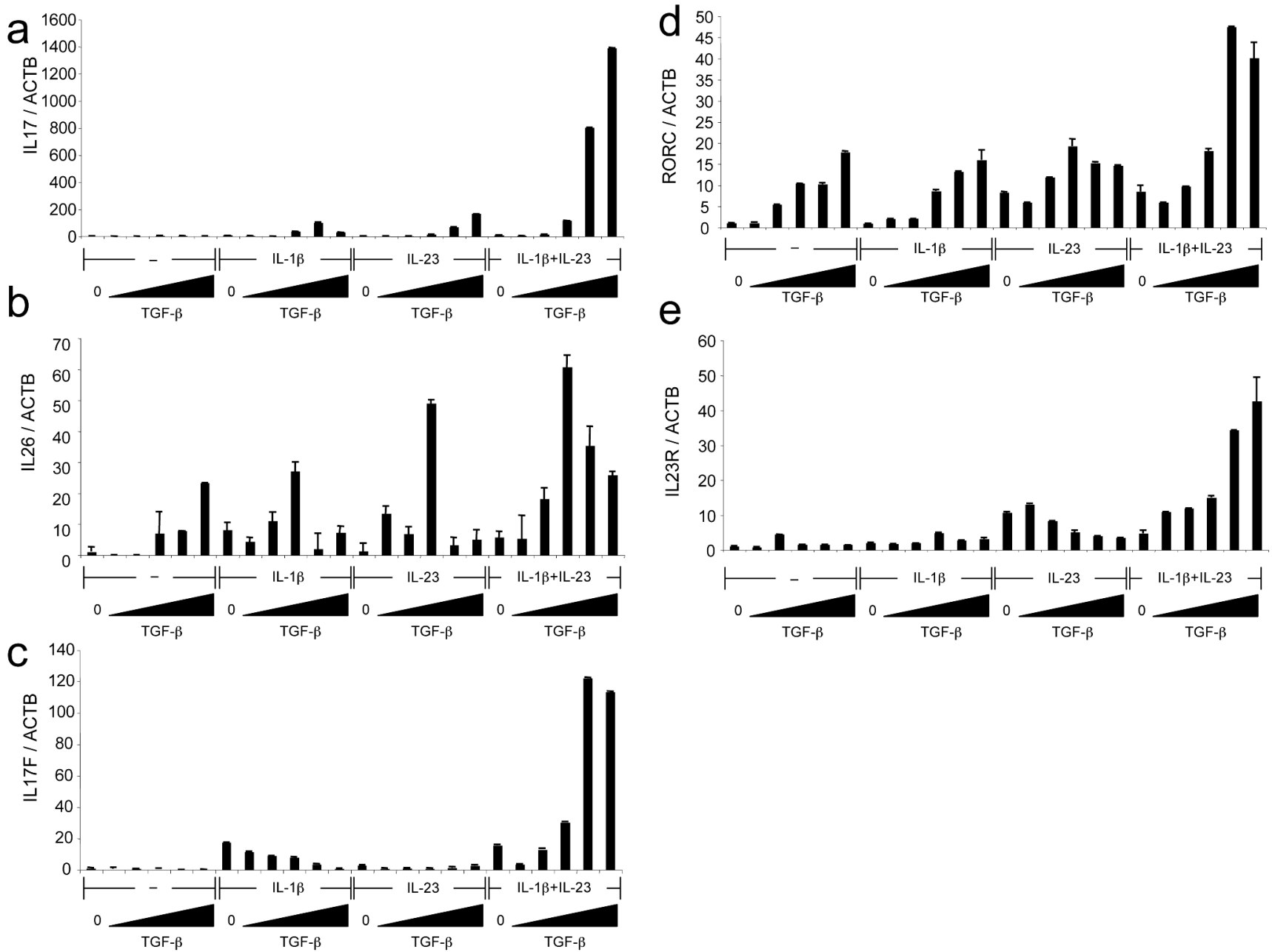

Figure 4. Induction of $I L 26, I L 17 F, I L 17, R O R C$ and $I L 23 R$ mRNAs during human $\mathrm{T}_{\mathrm{H}}-17$ cell differentiation

(a-c) Naive cord blood CD4 ${ }^{+} \mathrm{T}$ cells were cultivated with IL-2 alone or with IL-1 $\beta+$ IL-2, IL-23 + IL-2 or IL-23 + IL-1 $\beta$ + IL-2 with increasing concentrations of TGF- $\beta$. mRNA levels of $A C T B, I L 17$ (a), IL26 (b) and $I L I 7 F$ (c) were analyzed on day 6 following restimulation with PMA and ionomycin. (d, e) Naive cord blood CD4 ${ }^{+}$T cells were cultivated with IL-2 alone or with IL-1 $\beta+$ IL-2, IL-23 + IL-2 or IL-23 + IL-1 $\beta+$ IL-2 with increasing concentrations of TGF- $\beta$. mRNA levels of $A C T B, \operatorname{RORC}(\mathbf{d})$ and $I L 23 R(\mathbf{e})$ were analyzed on day 6 . Each panel is representative of three independent donors. 
a

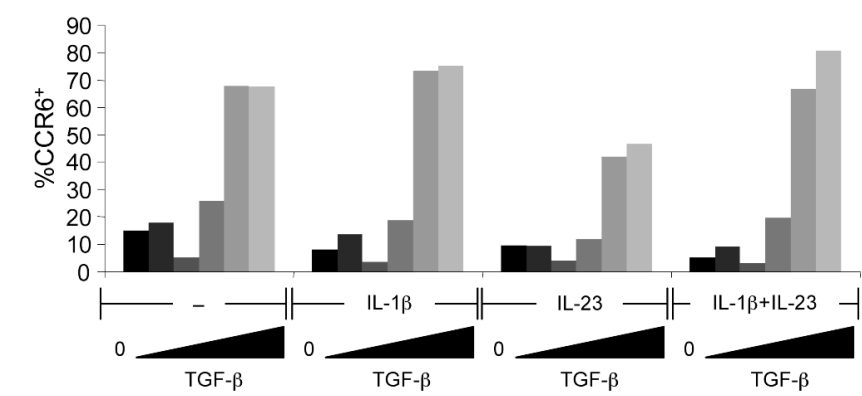

b

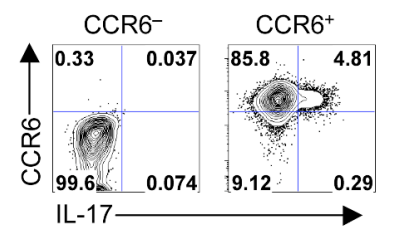

C

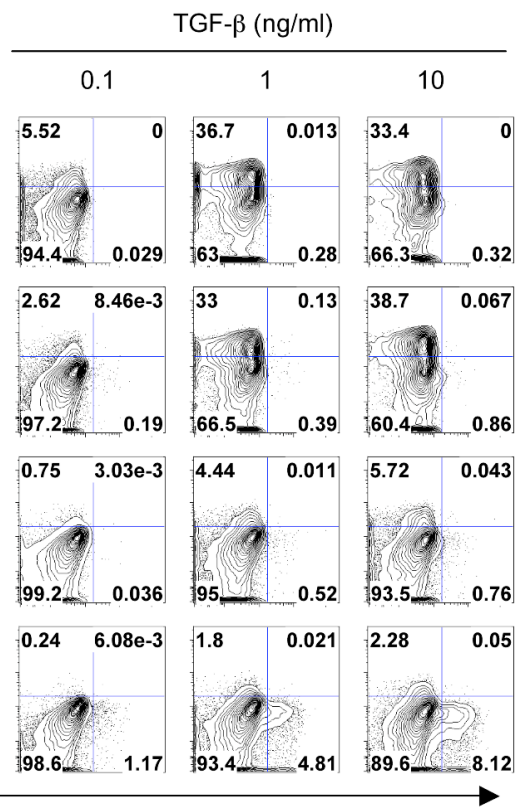

Figure 5. Expression of CCR6 and FOXP3 during human $\mathbf{T}_{\mathbf{H}^{-17}}$ cell differentiation

(a) Naive cord blood CD4 ${ }^{+} \mathrm{T}$ cells were cultivated with IL-2 alone or with IL-1 $\beta+$ IL-2, IL-23 + IL-2 or IL-23 + IL-1 $\beta+$ IL-2 with increasing concentrations of TGF- $\beta$. CCR6 expression was analyzed by surface staining at day 6 . (b) Naive cord blood CD4 ${ }^{+} \mathrm{T}$ cells were cultivated for 6 days in IL- $2+$ IL-23 + IL-1 $\beta+$ IL- $2+10 \mathrm{ng} / \mathrm{ml} \mathrm{TGF-} \beta$. CCR6 ${ }^{+}$and CCR6 ${ }^{-}$cells were sorted and intracellular IL-17 was analyzed. (c) Naive cord blood CD $4^{+}$T cells were cultivated with IL-2 alone or with IL-1 $\beta$ + IL-2, IL-23 + IL-2 or IL-23 + IL-1 $\beta+$ IL-2 with increasing concentrations of TGF- $\beta$. FOXP3 and IL-17 expression were analyzed at day 6 . Data are representative of four independent experiments. 